九州大学学術情報リポジトリ

Kyushu University Institutional Repository

Cropping Characteristics in Myanmar with Some Case Studies in Shan State and Mandalay Division

Egashira, Kazuhiko

Faculty of Agriculture, Kyushu University

Than, Aye Aye

Graduate School of Bioresource and Bioenvironmental Sciences, Kyushu University

https://doi.org/10.5109/9256

出版情報：九州大学大学院農学研究院紀要. 51 (2)，pp.373-382，2006-10-27. Faculty of Agriculture, Kyushu University

バージョン：

権利関係 : 


\title{
Cropping Characteristics in Myanmar with Some Case Studies in Shan State and Mandalay Division
}

\author{
Kazuhiko EGASHIRA* and Aye Aye Than ${ }^{1}$ \\ Laboratory of Soil Science, Division of Soil Science and Plant Production, \\ Department of Plant Resources, Faculty of Agriculture, \\ Kyushu University, 812-8581 Fukuoka, Japan \\ (Received June 27, 2006 and accepted July 24, 2006)
}

\begin{abstract}
General aspects of rainfall, irrigation and crop production in the whole country of Myanmar were evaluated according to the statistical data. After that, cropping characteristics in the highland region of Shan State (south) and semi-arid region of Mandalay Division were introduced as case studies, based on the information obtained through visiting of some research farms under the Department of Agricultural Research as well as observation in the field survey. It was found that crops were selected depending on the rainfall conditions of the regions under the rain-fed agriculture. Different pulses and edible-oil crops were mainly cultivated in the dryland agriculture in the semi-arid region of Mandalay Division. Various crops of upland rice, maize, wheat, garlic, potato, ginger, taro, sweet potato, vegetables and some pulses were involved in the crop combinations with increasing annual rainfall in the upland agriculture in the highland region of Shan state (south). The main cropping pattern in the lowland agriculture in the highland region of Shan State (south) was cropping of paddy rice (monsoon paddy) and following crops such as garlic, niger, chickpea, sunflower and tomato. Under irrigated condition, dual cropping of monsoon paddy and summer paddy was performed.
\end{abstract}

\section{INTRODUCTION}

Union of Myanmar is situated in the western end of Southeast Asia and is a member of ASEAN since 1997. The country is geographically located between $92^{\circ} 09^{\prime}$ to $101^{\circ} 10^{\prime} \mathrm{E}$ and $9^{\circ} 58^{\prime}$ to $28^{\circ} 31^{\prime} \mathrm{N}$ and is bordered with Bangladesh, India, China, Laos, and Thailand in the west to east through north and looks onto the Andaman Sea in the south. The western, northern and eastern parts of the country are hilly regions with altitudes varying from 915 to 2,134m (Ministry of Agriculture and Irrigation, 2000), leaving plains in the central and southern parts. The national land area of Myanmar is around 680 thousands $\mathrm{km}^{2}$ and the population is 52.17 millions in 2002 (quoted from homepage of the Ministry of Foreign Affairs of Japan: http://www.mofa.go.jp/mofaj/area/ myanmar/index.html (in Japanese)).

Agriculture and crop production in Myanmar are more or less strongly affected by the rainfall conditions, because the irrigation rate of the arable-land still remains in 17\% in 1999/2000 in Myanmar (Kurosawa and Egashira, 2004) and crop cultivation is performed mostly under the rain-fed condition. The whole country of Myanmar belongs to the tropical to subtropical monsoon climate. The whole year is separated into following three seasons: hot, rainy, and dry-cold. In general, the hot season lasts from middle February to middle May, the rainy season from middle May to middle October, and the dry-cold season from middle October to middle February. According to the document of Ministry of

\footnotetext{
1 Laboratory of Soil Science, Division of Soil Science and Plant Production, Department of Plant Resources, Graduate School of Bioresource and Bioenvironmental Sciences, Kyushu University, 812-8581 Fukuoka, Japan

* Corresponding author (E-mail: kegashi@agr.kyushu-u.ac.jp)
}

Agriculture and Irrigation (2000), the mean annual rainfall varies widely from $762 \sim 1,016 \mathrm{~mm}$ in the central core to $2,540 \sim 5,080 \mathrm{~mm}$ in the coastal and hilly regions. The temperature in the southern part of the country differs a little from season to season. In the central plain, however, seasonal variation of temperature lies in the magnitude of about $40-43^{\circ} \mathrm{C}$ in the hot season and $10-15^{\circ} \mathrm{C}$ in the cold season.

We had a short field survey on land use in the highland region of Shan State (south) and in the semi-arid region of Mandalay Division and visited some research farms under the Department of Agricultural Research, Ministry of Agriculture and Irrigation, in late March 2006. Here, Shan State is subdivided into Shan State (north), Shan State (south) and Shan State (east). The time of the survey was just in the hot (summer) season, and the weather condition was hot and dry. The land was hardly cultivated with crops due to lack of water or post-harvest season. Although the timing was not good for the land use survey, we got some information on the land use and cropping characteristics in these regions.

In the current report, general aspects of rainfall conditions, irrigation in the agricultural land, and crop production in Myanmar were first described and discussed using statistical data. Then cropping characteristics in the highland region of Shan State (south) and in the semi-arid region of Mandalay Division were introduced as case studies with information obtained by visiting Taryaw, Aung Ban and Nyaung Oo Research Farms and through field survey.

\section{RAINFALL CONDITIONS}

\section{Annual rainfall}

Crop production or cultivation in the tropics and subtropics is controlled by the amount and distribution 
of rainfall. It is difficult to get sufficient production under the rain-fed condition especially in the dry season, but water requirement for growing considerably varies with crops and with yield levels for a crop. Table 1 shows the annual rainfall of the stations in Myanmar, which is the average of 1992 to 2001 and was recorded at the meteorological stations and rainfall stations of the Department of Meteorology and Hydrology. Locations of Division and State to which the stations belong are illustrated in Fig. 1.

Annual rainfall varied remarkably from station to station; the highest rainfall amount of 5,691 mm was recorded at Ye of Mon State and the lowest amount of $657 \mathrm{~mm}$ was at Nyaung Oo of Mandalay Division. As a whole, the annual rainfall was greater for Kayin State, Mon State and Tanintharyi Division of the peninsular region and Rakhine State of the western side while lower for Mnadalay and Magway Divisions of the central region. The region of Mandalay and Magway Divisions including a part of Sagaing Division has been called as the central Myanmar and is characterized by the semiarid climate. Annual rainfall exceeded 1,000 mm in other Divisions and States and was in a range of 1,267 to $1,468 \mathrm{~mm}$ at the three stations in Shan State.

\section{Monthly rainfall}

Figure 2 shows the monthly rainfall at the four stations of Yangon, Mandalay, Magway and Taunggyi selected from Table 1, which is the average of 1992 to 2001 and was recorded at the meteorological stations

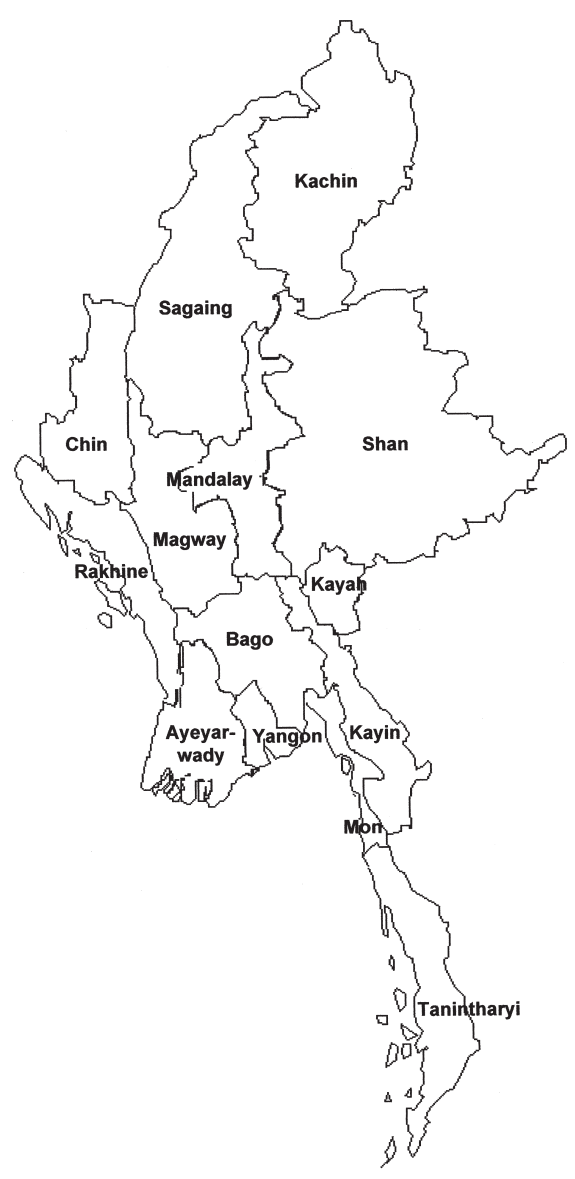

Figure 1. Administrative map of Myanmar.

Table 1. Annual rainfall at some stations in Myanmar

\begin{tabular}{|c|c|c|c|}
\hline $\begin{array}{l}\text { Division/State } \\
\text { Station }\end{array}$ & $\begin{array}{l}\text { Annual rainfall (mm) } \\
\text { (Average of 1992-2001) }\end{array}$ & $\begin{array}{l}\text { Division/State } \\
\text { Station }\end{array}$ & $\begin{array}{l}\text { Annual rainfall (mm) } \\
\text { (Average of 1992-2001) }\end{array}$ \\
\hline $\begin{array}{c}1 \text { Kachin State } \\
\text { Myitkyina } \\
\text { Mohnyin }\end{array}$ & $\begin{array}{l}2481 \\
1810\end{array}$ & $\begin{array}{l}8 \text { Magway Division } \\
\text { Magway } \\
\text { Gangaw* }\end{array}$ & $\begin{array}{r}905 \\
1221\end{array}$ \\
\hline $\begin{array}{l}2 \text { Kayah State } \\
\text { Loikaw }\end{array}$ & 1020 & 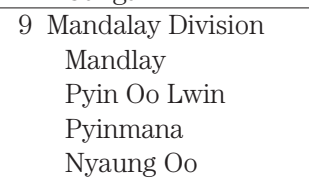 & $\begin{array}{r}866 \\
1395 \\
1416 \\
657\end{array}$ \\
\hline $\begin{array}{c}3 \text { Kayin State } \\
\text { Hpa-an }\end{array}$ & 3990 & $\begin{array}{l}10 \text { Mon State } \\
\text { Mawlamyine } \\
\text { Ye }\end{array}$ & $\begin{array}{l}5106 \\
5691\end{array}$ \\
\hline $\begin{array}{l}4 \text { Chin State } \\
\text { Falam } \\
\text { Hakha }\end{array}$ & $\begin{array}{l}1486 \\
1864\end{array}$ & $\begin{array}{l}11 \text { Rakhine State } \\
\text { Sittwe } \\
\text { Thantwe }\end{array}$ & $\begin{array}{l}4932 \\
5594\end{array}$ \\
\hline $\begin{array}{c}5 \text { Sagaing Division } \\
\text { Katha } \\
\text { Mawlaik } \\
\text { Monywa } \\
\text { Shwe Bo } \\
\text { Hkamti }\end{array}$ & $\begin{array}{r}1566 \\
1745 \\
726 \\
884 \\
3606\end{array}$ & $\begin{array}{l}12 \text { Yangon Division } \\
\text { Yangon }\end{array}$ & 2903 \\
\hline 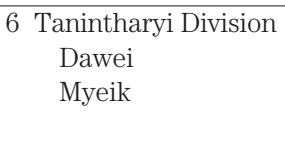 & $\begin{array}{l}5663 \\
3997\end{array}$ & $\begin{array}{c}13 \text { Shan State } \\
\text { Lashio } \\
\text { Taunggyi } \\
\text { Keng Tung }\end{array}$ & $\begin{array}{l}1326 \\
1468 \\
1267\end{array}$ \\
\hline $\begin{array}{l}7 \text { Bago Division } \\
\text { Bago } \\
\text { Pyay }\end{array}$ & $\begin{array}{l}3320 \\
1169\end{array}$ & $\begin{array}{l}14 \text { Ayeyarwady Division } \\
\text { Pathein }\end{array}$ & 2988 \\
\hline
\end{tabular}

Recorded at the meteorological stations and rainfall stations of the Department of Meteorology and Hydrology.

* Average of 1992-2000. 

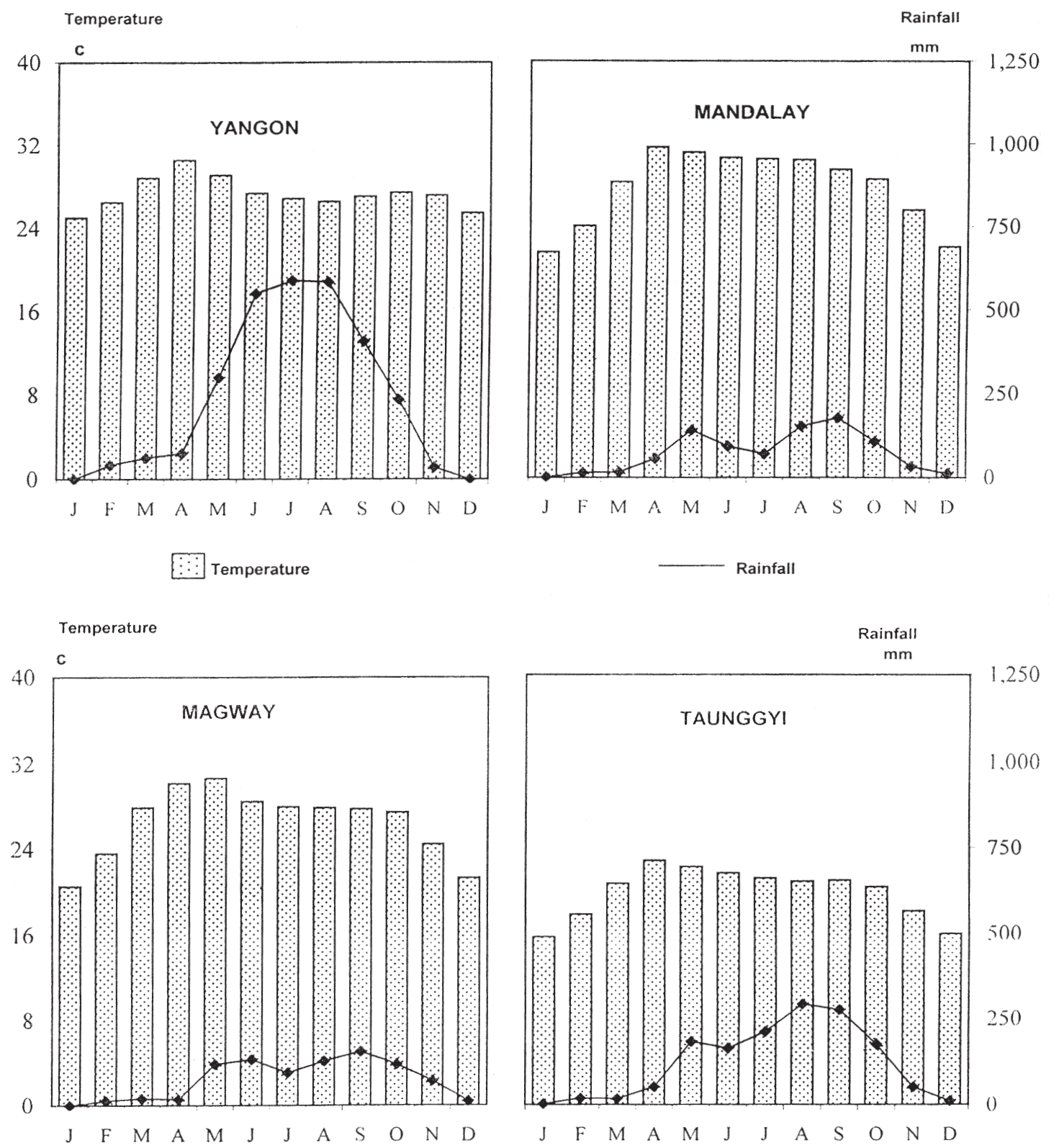

Figure 2. Monthly rainfall and temperature at the selected stations in Myanmar.

(Recorded at the meteorological stations and rainfall stations of the Department of Meteorology and Hydrology)

and rainfall stations of the Department of Meteorology and Hydrology. The monthly rainfall pattern of the respective stations clearly indicates that the monsoon rainfall starts in May and lasts to October irrespective of the amount of annual rainfall but that the amount of monthly rainfall considerably varies from station to station. The maximum monthly rainfall is around 600 $\mathrm{mm}$ at Yangon while about 175 and $160 \mathrm{~mm}$ at Mandalay and Magway, respectively. In addition, Yangon showed the unimodal rainfall pattern, but the bimodal rainfall pattern was noticed at Mandalay and Magway. Taunggyi is in the intermediate position between the two patterns. Mandalay and Magway are located in the semi-arid region of the central Myanmar and are characterized by the relatively low monthly rainfall in the rainy (monsoon) season and by the bimodal rainfall pattern with July break of rainfall. These rainfall conditions seem to affect seriously the crop production in the semi-arid region.

\section{IRRIGATION IN THE AGRICULTURAL LAND}

Table 2 shows agricultural area and irrigated agricultural area, which were quoted from FAO Statistical Databases (http://www.fao.org), and the irrigation rate calculated as a ratio of the latter to the former. Data are shown to Myanmar and some other countries surrounding or neighboring Myanmar. Agricultural and irrigated agricultural areas are expressed as three-year averages of 2003 to 2001 and of 1993 to 1991 , so that we can minimize the annual variation of data and understand the change occurring during the recent 10 years. In addition, situation of agricultural irrigation in Myanmar is easily compared with situation of those countries. 
Table 2. Irrigation in the agricultural land of Myanmar and some other countries

\begin{tabular}{|c|c|c|c|c|c|c|c|c|c|}
\hline \multirow[b]{2}{*}{ Country } & \multicolumn{3}{|c|}{ Agricultural area (1000 ha) } & \multicolumn{3}{|c|}{ Irrigated agricultural area (1000 ha) } & \multicolumn{3}{|c|}{ Irrigation rate (\%) } \\
\hline & $\begin{array}{c}2003-2001 \\
\text { (a) }\end{array}$ & $\begin{array}{c}1993-1991 \\
\text { (b) }\end{array}$ & $\begin{array}{l}\text { Increasing } \\
\text { rate }(\mathrm{a} / \mathrm{b})\end{array}$ & $\begin{array}{c}2003-2001 \\
\text { (c) }\end{array}$ & $\begin{array}{c}1993-1991 \\
\text { (d) }\end{array}$ & $\begin{array}{l}\text { Increasing } \\
\text { rate }(\mathrm{c} / \mathrm{d})\end{array}$ & $\begin{array}{c}2003-2001 \\
(\mathrm{c} / \mathrm{a}=\mathrm{e})\end{array}$ & $\begin{array}{c}1993-1991 \\
(d / b=f)\end{array}$ & $\begin{array}{l}\text { Increasing } \\
\text { rate }(\mathrm{e} / \mathrm{f})\end{array}$ \\
\hline Myanmar & 11052 & 10420 & 1.061 & 1922 & 1023 & 1.879 & 17.39 & 9.82 & 1.771 \\
\hline Bangladesh & 9044 & 9166 & 0.987 & 4581 & 3169 & 1.446 & 50.65 & 34.57 & 1.465 \\
\hline Thailand & 19591 & 21378 & 0.916 & 4986 & 4440 & 1.123 & 25.45 & 20.77 & 1.225 \\
\hline Laos & 1876 & 1664 & 1.127 & 175 & 145 & 1.207 & 9.33 & 8.71 & 1.071 \\
\hline Cambodia & 5307 & 5306 & 1.000 & 270 & 260 & 1.038 & 5.09 & 4.90 & 1.039 \\
\hline Viet Nam & 9520 & 6954 & 1.369 & 3000 & 2933 & 1.023 & 31.51 & 42.18 & 0.747 \\
\hline
\end{tabular}

Quoted from FAO Statistical Databases: http://www.fao.org.

\section{General}

Agricultural area of Myanmar is around 11 million ha in 2003-2001 and increased by 632 thousand ha with an increasing rate of 1.061 from 1993-1991. Agricultural area decreased in Bangladesh and Thailand from 19931991 to 2003-2001 but considerably increased in Viet Nam during the same duration. Irrigated agricultural area of Myanmar remarkably increased from 1,023 thousand ha in 1993-1991 to 1,922 thousand ha in 2003-2001, and the irrigation rate was attained to $17.4 \%$ in $2003-$ 2001. However, the irrigation rate of Myanmar is still lower than that of Bangladesh, Thailand and Viet Nam, although higher than that of Laos and Cambodia, and remains in one-third of Bangladesh, two-thirds of Thailand and about a half of Viet Nam at the time of 2003-2001.

\section{Situation in Myanmar}

Based on the statistical data shown in Table 2, it can be speculated as follows. Shifting of non-irrigated to irrigated agricultural land is steadily advancing in recent years in Myanmar. This is probably due to the Government policy to develop the agricultural sector and to keep sustainability of land. The summer rice program was started in 1992 by using short-lived high-yielding varieties together with proper irrigation system (Ministry of Agriculture and Irrigation, 2004). It is considered that construction of dams/reservoirs and irrigation facilities was advanced by the financial support of national and international organizations.

The fact that only $17 \%$ of agricultural land is irrigated in 2003-2001 imagines that irrigation is focused mainly on paddy field, leaving upland field in the hardly irrigated condition. In this context, occupation of the irrigated paddy field in the total irrigated area was 74.8\% in $1990-91,82.5 \%$ in $1995-96,76.5 \%$ in $2000-01$, and $73.4 \%$ in 2001-02 (data source: Department of Settlement and Land Records, Ministry of Agriculture and Irrigation). Occupation of paddy in the total irrigated area exceeds $70 \%$ as expected, but its decreasing tendency in recent years suggests gradual advancement of irrigation to upland crops. In Myanmar, irrigation is for the most part due to surface irrigation, and the area irrigated by groundwater (well) remains in 5\% of the total irrigated area in 2001-02 (data source: Department of Settlement and Land Records, Ministry of Agriculture and Irrigation).

\section{Situation in Bangladesh and Thailand}

Bangladesh and Thailand exhibit qualitatively the same tendency in the irrigation of the agricultural land. Namely, agricultural area decreased but irrigated agricultural area increased between 1993-1991 and 20032001. However, the great difference in the irrigation rate between the two countries indicates that paddy cultivation is the major form of agriculture in Bangladesh but that upland agriculture is mainly performed in Thailand.

\section{Situation in Cambodia and Laos}

Cambodia is over Laos in both agricultural and irrigated agricultural areas, although the values of both countries are remarkably low compared with the values of other four countries, but their increasing rate during the ten years is grater for Laos than for Cambodia. The irrigation rate of Laos is near double of that of Cambodia but is still below 10\% in 2003-2001.

\section{Situation in Viet Nam}

In Viet Nam agricultural area has considerably increased between 1993-1991 and 2003-2001, whereas irrigated agricultural area hardly changed during the same ten years. It means that increase in the agricultural area has been caused by the new development of the land without irrigation and that easily irrigated agricultural land had been already irrigated until 1993-1991. Egashira (2002a) reported that increase in the cultivated land area in Viet Nam during 1985 and 1996 was covered by $64 \%$ by the increase in the Mekong River Delta region but that increase after 1996 was caused mostly by the increase in the Central Highlands and North East South regions with development of plantation agriculture of industrial crops.

\section{CROP PRODUCTION}

\section{General}

Table 3 shows area harvested, yield and production of some crops in Myanmar, which were quoted from FAO Statistical Databases (http://www.fao.org). The data are expressed as three-year averages of 2003 to 2001 and of 1993 to 1991, so that we can minimize the 
Table 3. Crop production in Myanmar

\begin{tabular}{|c|c|c|c|c|c|c|c|c|c|c|}
\hline \multirow[b]{2}{*}{ Crop } & & \multicolumn{3}{|c|}{ Area harvested (1000 ha) } & \multicolumn{3}{|c|}{ Yield (Mg/ha) } & \multicolumn{3}{|c|}{ Production (Gg) } \\
\hline & & $\begin{array}{c}2003-2001 \\
\text { (a) }\end{array}$ & $\begin{array}{c}1993-1991 \\
\text { (b) }\end{array}$ & $\begin{array}{l}\text { Increasing } \\
\text { rate }(\mathrm{a} / \mathrm{b})\end{array}$ & $\begin{array}{c}2003-2001 \\
\text { (c) }\end{array}$ & $\begin{array}{c}1993-1991 \\
\text { (d) }\end{array}$ & $\begin{array}{l}\text { Increasing } \\
\text { rate }(\mathrm{c} / \mathrm{d})\end{array}$ & $\begin{array}{c}2003-2001 \\
\text { (e) }\end{array}$ & $\begin{array}{c}1993-1991 \\
\text { (f) }\end{array}$ & $\begin{array}{l}\text { Increasing } \\
\text { rate(e/f) }\end{array}$ \\
\hline & Rice, Paddy & 6440.5 & 5039.3 & 1.278 & 3.460 & 2.959 & 1.169 & 22289.1 & 14935.9 & 1.492 \\
\hline \multirow{3}{*}{$\begin{array}{l}\text { Other } \\
\text { cereals }\end{array}$} & Wheat & 85.8 & 143.0 & 0.600 & 1.271 & 0.944 & 1.346 & 109.2 & 135.1 & 0.808 \\
\hline & Maize & 267.7 & 131.5 & 2.035 & 2.284 & 1.531 & 1.492 & 613.4 & 201.4 & 3.046 \\
\hline & Millet & 230.9 & 195.4 & 1.182 & 0.722 & 0.683 & 1.057 & 166.8 & 133.6 & 1.249 \\
\hline \multirow[t]{6}{*}{ Pulses } & Beans, Dry & 1823.5 & 717.5 & 2.541 & 0.835 & 0.656 & 1.273 & 1510.8 & 471.2 & 3.206 \\
\hline & Pigeon Peas & 453.7 & 126.3 & 3.592 & 0.930 & 0.625 & 1.488 & 423.7 & 80.4 & 5.270 \\
\hline & Chick-Peas & 188.8 & 157.6 & 1.198 & 0.971 & 0.658 & 1.476 & 186.4 & 103.7 & 1.797 \\
\hline & Cow Peas, Dry & 133.7 & 32.6 & 4.10 & 0.827 & 0.542 & 1.526 & 110.7 & 17.7 & 6.25 \\
\hline & Soybeans & 122.4 & 34.0 & 3.60 & 1.040 & 0.813 & 1.279 & 127.8 & 27.7 & 4.61 \\
\hline & Peas, Dry & 40.7 & 28.5 & 1.428 & 0.802 & 0.572 & 1.402 & 32.7 & 16.4 & 1.994 \\
\hline \multirow{3}{*}{$\begin{array}{l}\text { Edible-oil } \\
\text { crops }\end{array}$} & Sesame, Seed & 1269.8 & 929.3 & 1.366 & 0.348 & 0.223 & 1.561 & 442.3 & 207.8 & 2.128 \\
\hline & Groundnuts in Shell & 602.6 & 494.0 & 1.220 & 1.308 & 0.864 & 1.514 & 788.6 & 427.7 & 1.844 \\
\hline & Sunflower Seed & 496.5 & 140.6 & 3.531 & 0.595 & 0.661 & 0.900 & 295.6 & 93.0 & 3.178 \\
\hline \multirow{3}{*}{$\begin{array}{l}\text { Industrial } \\
\text { crops }\end{array}$} & Seed Cotton & 280.7 & 152.1 & 1.845 & 0.537 & 0.425 & 1.264 & 150.6 & 64.6 & 2.331 \\
\hline & Sugar Cane & 147.7 & 59.7 & 2.474 & 44.633 & 44.221 & 1.009 & 6593.7 & 2648.7 & 2.489 \\
\hline & Jute & 45.9 & 33.2 & 1.383 & 0.934 & 0.869 & 1.075 & 43.0 & 28.4 & 1.514 \\
\hline \multirow{6}{*}{$\begin{array}{l}\text { Kitchen } \\
\text { crops }\end{array}$} & Onions, Dry & 57.7 & 24.2 & 2.38 & 11.312 & 7.235 & 1.564 & 652.6 & 174.5 & 3.740 \\
\hline & Potatos & 30.6 & 15.1 & 2.03 & 11.672 & 9.638 & 1.211 & 357.6 & 145.2 & 2.463 \\
\hline & Garlic & 19.6 & 11.4 & 1.72 & 5.059 & 3.621 & 1.397 & 99.8 & 41.3 & 2.416 \\
\hline & Cassava & 10.7 & 5.8 & 1.84 & 11.165 & 9.519 & 1.173 & 120.3 & 55.0 & 2.187 \\
\hline & Sweet Potatos & 8.9 & 5.0 & 1.78 & 6.678 & 5.380 & 1.241 & 59.1 & 26.9 & 2.20 \\
\hline & Vegetables Fresh nes & 215.0 & 149.9 & 1.434 & 13.565 & 13.458 & 1.008 & 2916.7 & 2016.7 & 1.446 \\
\hline
\end{tabular}

Quoted from FAO Statistical Databases: http://www.fao.org.

annual variation of data and understand the change occurring during the recent 10 years. Major crops in Myanmar are paddy rice, pulses and edible-oil crops. The area harvested in 2003-2001 was 6.44 million ha for paddy rice, 2.76 million ha for pulses, and 2.37 million ha for edible-oil crops, occupying 49.6, 21.3, and 18.3\%, respectively, of the summation of area harvested.

\section{Paddy rice and other cereals}

Paddy rice is the most important crop in Myanmar. Some portions of rice products are exported. The area harvested for paddy rice occupied $49.6 \%$ of the summation of area harvested for the crops shown in Table 3 in 2003-2001, and it was reduced from 58.4\% in 1993-1991. The yield was $3.46 \mathrm{Mg} / \mathrm{ha}$ in $2003-2001$ and increased from $2.96 \mathrm{Mg} / \mathrm{ha}$ in 1993-1991. Among the six countries shown in Table 2, the yield of paddy rice in Myanmar was the second highest following Viet Nam (Egashira, 2002b). Both area harvested and yield of paddy rice increased between 1993-1991 and 2003-2001. Production also increased by 1.5 times during the same duration, and contribution of increase in the area harvested was greater than that of the yield.

Generally speaking, cultivation in the rainy season (monsoon paddy) is the main rice cultivation in Myanmar, and cultivation in the hot season (summer paddy) is done under utilization of irrigation water. In the average of the three seasons of 1998-99 to 1996-97, the planted (sown) area was 4.92 million ha to monsoon paddy and 0.89 million ha to summer paddy (Ministry of Agriculture and Irrigation, 2000). The planted area of summer rice remains in $15.3 \%$ of the total rice planted area, although the summer rice program was started in
1992 as stated in the above.

Among other cereals, production of maize increased by 3.0 times from 1993-1991 to 2003-2001, and its increase was contributed in a greater extent by increase in the area harvested. Maize is exported as well as use for feeding of livestock and poultries. In contrast to paddy rice and maize, both area harvested and production of wheat decreased more or less strongly between 1993-1991 and 2003-2001. The area harvested of wheat was only $13 \%$ of that of paddy rice in 2003-2001. It is imagined that the wheat field has been substituted partially by the pulses field during the ten years.

\section{Pulses}

Different kinds of pulses are cropped in Myanmar. According to Myanmar Agriculture in Brief (Ministry of Agriculture and Irrigation, 2004), Myanmar is presently standing as a leading country of pulses production among ASEAN member countries. Beans probably including green gram (mung bean), black gram, butter bean, kidney bean, lab-lab bean, and some other Myanmar-name beans, occupied about two-thirds of the total for pulses in both area harvested and production in 2003-2001. In this context, green gram and black gram occupied 33.8 and $29.3 \%$ in the area harvested of pulses in 2000-01 (data source: Department of Settlement and Land Records, Ministry of Agriculture and Irrigation).

The increasing rate of production between 19931991 and 2003-2001 was highest for cow peas, followed by pigeon peas and soybeans, and increase in the production was contributed greatly by increase in the area harvested. Pulses are demanded for domestic consumption as well as export as the cash crop to foreign coun- 
tries. Export of pulses increased from 17 Gg in 1988-89 to 1,000 Gg in 2001-02 (Ministry of Agriculture and Irrigation, 2004), and major exportable varieties of pulses are chickpea, pigeon pea, cow pea, soybean, green gram, black gram and kidney bean. Great increase in the production of cow peas, pigeon peas and soybeans supports the recent increasing request for export of pulses.

\section{Edible-oil crops}

Sesame, groundnut, sunflower, soybean and oil palm are cultivated as edible-oil crops in Myanmar, although only the first three crops are listed in Table 3 . The edible-oil crops are cultivated for domestic use; Myanmar food is characterized by using a lot of plant oil made from these crops. Among edible-oil crops, the highest increasing rate in the production between 19931991 and 2003-2001 was observed for sunflower. Its increase was supported by only increase in the area harvested, because the yield declined somewhat during that duration. In contrast, increase in the production of sesame and groundnuts was contributed in a greater extent by increase in the yield.

\section{Industrial crops}

Cotton, sugarcane, jute and rubber are cultivated as industrial crops. Four major crops in Myanmar, recognized as main pillars, are cotton and sugarcane in addition to paddy rice and pulses (Ministry of Agriculture and Irrigation, 2004). Concerted efforts are being made for increased production of them, in order to increase the foreign exchange earning from the agricultural sector. Increase in the production of cotton and sugarcane from 1993-1991 to 2003-2001 was mostly attained by increase in the area harvested, and contribution of increase in the yield was a little or hardly observed.

\section{Kitchen crops and vegetables}

Production of onions, potatos, garlic, cassava and sweet potatos as kitchen crops increased more than double from 1993-1991 to 2003-2001, suggesting increasing demand for domestic consumption in houses and restaurants. Their increases were all mainly contributed by increase in the area harvested. The area harvested of kitchen crops were in the order of onions $>$ potatos $>$ garlic $>$ cassava $>$ sweet potatos. The area harvested in total for kitchen crops was 127.5 thousand ha in 2003-2001. It was considerably lower than the area harvested for vegetables of 215.0 thousand ha in the same year.

\section{Factors contributing to increase in the production}

As recognized from Table 3, all crops except wheat showed the increased production during the ten years from 1993-1991 to 2003-2001. Increase in the production of those crops was for the most part contributed by increase in the area harvested than increase in the yield. In this context, Table 4 shows temporal variation of gross area harvested, gross area planted, and their ratio in Myanmar. It is understood that increase in the area harvested is resulted from both increase in the area planted and increase in the area harvested itself due to decrease in the gross area destroyed, since the ratio of gross area harvested to gross area planted gradually increased with some fluctuations in advancement of year.

Several causes can be considered to keep the agricultural land harvested. They are settlement of irrigation facilities, flood protection works, control of water resources, application of agricultural chemicals to prevent crops from damages by diseases and insects, and breeding and provision of resistant varieties. Socioeconomic pressure for cultivation of fallow land in addition to development of agricultural land may be considered as a reason for increase in the area planted. The relatively small contribution of the yield increase to the production increase suggests insufficient and/or improper application of chemical fertilizes in crop cultivation.

\section{SOME CASE STUDIES IN SHAN STATE (SOUTH) AND MANDALAY DIVISION}

We visited the Taryaw, Aung Ban and Nyaung Oo Research Farms under the Department of Agricultural Research, Ministry of Agriculture and Irrigation, in late March 2006. The Taryaw and Aung Ban Research Farms cover the lowland and upland agriculture, respectively, in the highland region of Shan State (south). The Nyaung Oo Research Farm covers the dryland agriculture in the semi-arid region of Mandalay Division. The following sections are described based on the information obtained through discussion with staffs of the research farms and exhibitions or introductory pamphlets prepared by the research farms and through field survey in and around the research farms.

Table 4. Temporal variation of gross area harvested, gross area planted, and their ratio in Myanmar

\begin{tabular}{l|r|r|r|r|r|r|r|r|r|r}
\hline Year & $1980-81$ & $1985-86$ & $1990-91$ & $1995-96$ & $1996-97$ & $1997-98$ & $1998-99$ & $1999-00$ & $2000-01$ & $2001-02$ (p.a) \\
\hline $\begin{array}{l}\text { Gross area } \\
\text { harvested (a) } \\
\text { (1000 ha) }\end{array}$ & 8721 & 9318 & 9286 & 12080 & 11762 & 11286 & 12038 & 13933 & 14773 & 15205 \\
\hline $\begin{array}{l}\text { Gross area } \\
\text { planted (b) } \\
\text { (1000 ha) }\end{array}$ & 10038 & 10385 & 10127 & 12884 & 12311 & 12277 & 13307 & 14804 & 15450 & 15845 \\
\hline Ratio (a/b) & 0.869 & 0.897 & 0.917 & 0.938 & 0.955 & 0.919 & 0.905 & 0.941 & 0.956 & 0.960 \\
\hline
\end{tabular}

Data source: Department of Settlement and Land Records, Ministry of Agriculture and Irrigation. 
TARYAW RESEARCH FARM AND LOWLAND AGRICULTURE IN THE HIGHL AND, HIGHLAND REGION

\section{Location and fundamental data of the Taryaw Research Farm}

The Tayraw Research Farm is located in Taunggyi Township, Taunggyi District, Shan State (south) and was established on July 5 in 1998. It covers the lowland agriculture in the highland region of Shan State (south). There are 3 staffs and 9 workers in the research farm, and the area controlled by the research farm is 10.1 ha (25 acres). The following is fundamental data on the Tayraw Research Farm and soil in the farm field: elevation is $906.8 \mathrm{~m}$ (2,975 feet) above sea level; mean annual rainfall is $1,130 \mathrm{~mm}$ (44.50 inches); average rainy days in a year is 98 ; mean maximum monthly temperature is $30.65{ }^{\circ} \mathrm{C}$ in April and mean minimum monthly temperature is $5.58^{\circ} \mathrm{C}$ in January; soil type is clayey soil; soil pH is 8.2. The roles of the research farm in Myanmar are, in general, research, propagation of seeds with producing of them, and extension of cultivation techniques to extension workers and farmers. Extension activity or explanation to extension workers and farmers at the research farm is carried out one time in a year; the day is called as "field day".

\section{Research activities and output in the Taryaw Research Farm}

Main research activities in the Taryaw Research Farm are as follows: 1. selection of lowland rice, maize, soybean and sunflower in most cases and of tomato and wheat sometimes without breeding work; 2 . establishment of cropping patterns on cultivation of monsoon paddy and following crops such as chickpea, sunflower and wheat; 3. improvement of production technology for paddy rice and other crops. Table 5 shows paddy rice varieties suitable to the cultivation in the lowland area of Shan State (south), which had been exhibited in the Taryaw Research Farm. Among those varieties, Hexi-30 was selected as a cold-tolerant variety in the Taryaw Research Farm. The yield given in Table 5 may be a potential yield, because it remarkably exceeds the national average yield of $3.46 \mathrm{Mg} / \mathrm{ha}$ in 2003-2001 shown in Table 3.

\section{Cropping}

Rice is mainly cultivated in the rainy season (monsoon paddy) and, if irrigation water is available, cultivat- ed in the hot season (summer paddy). In this case dual cropping of paddy rice becomes possible, but it is limited to the paddy field near irrigation sources. Generally in the lowland area of Shan State (south), summer rice is seeded in March, transplanted in April and harvested in July, and monsoon paddy is transplanted in July and harvested in November. In the field survey we saw summer rice in the seedling stage or just in transplantation near the Inle Lake where paddy rice cultivation is practiced by one month earlier than other places to prevent rice from flooding caused by overflow of the Inle Lake in October. In the cropping patterns of monsoon paddy and following crops, monsoon paddy is usually combined with garlic, niger, chickpea, sunflower and tomato in the farmers' field. In this cropping pattern, after harvesting of monsoon paddy in November, garlic and niger are directly seeded without plowing, while soil is roughly plowed before broadcasting/transplanting of chickpea, sunflower and tomato seeds to prevent a crop from excess moisture injury. Supplementary irrigation and fertilization are requested for cultivation of garlic and tomato.

\section{AUNG BAN RESEARCH FARM AND UPLAND AGRICULTURE IN THE HIGHL AND, HIGHLAND REGION}

\section{Location and fundamental data of the Aung Ban Research Farm}

The Aung Ban Research Farm is located in Kalaw Township, Taunggyi District, Shan State (south). It was established in 1980 as the Potato Research Farm, and renamed as Hillside Crops Research Farm in 1986 and as Hybrid Corn Seed Production Project Farm in 2003. It covers the upland agriculture in the highland region of Shan State (south). There are 12 staffs in the Aung Ban Research Farm. Among them, 6 persons are Bachelor of Agricultural Science, 4 persons Diploma in Agricultural Science, and 2 persons official staffs. It is located $58 \mathrm{~km}$ far from Taunggyi center. The following is fundamental data on the Aung Ban Research Farm and soil in the farm field: elevation is $1286.0 \mathrm{~m}$ (4,219 feet) above sea level; annual rainfall is $1,047 \mathrm{~mm}$ (41.24 inches) in 10-year average and 1,524 mm (60inches) in 2005; number of rainy days in a year is 89 in 10-year average and 97 in 2005; mean maximum monthly temperature is $30.5^{\circ} \mathrm{C}$ in April and mean minimum monthly temperature is $4.3^{\circ} \mathrm{C}$ in January; soil $\mathrm{pH}$ is 3.5 to 5.5. Total area of the research farm is 54.2 ha (134acres). Cultivated

Table 5. Suitable rice varieties in the lowland area of Shan State (south)

\begin{tabular}{|c|c|c|c|c|}
\hline Rice variety & $\begin{array}{l}\text { Growing period } \\
\text { (day) }\end{array}$ & $\begin{array}{l}\text { Plant height } \\
(\mathrm{cm})\end{array}$ & $\begin{array}{l}\text { Number of panicles } \\
\text { per plant }\end{array}$ & $\begin{array}{l}\text { Yield } \\
\text { (Mg/ha) }\end{array}$ \\
\hline $\begin{array}{l}\text { Shwe Yin Aye } \\
\text { Hexi-30 } \\
\text { Sin Shwe War } \\
\text { Yezin Lone Thwe }\end{array}$ & $\begin{array}{l}135 \\
115 \\
125 \\
125\end{array}$ & $\begin{array}{r}107-122(3.5-4.0) \\
91-107(3.0-3.5) \\
91-107(3.0-3.5) \\
91-107(3.0-3.5)\end{array}$ & $\begin{array}{l}7-9 \\
6-8 \\
6-8 \\
8-12\end{array}$ & $\begin{array}{l}5.16-6.19(100-120) \\
4.13-4.64(80-90) \\
3.61-4.13(70-80) \\
6.19-7.22(120-140)\end{array}$ \\
\hline
\end{tabular}

1. Expression of plant height was converted to $\mathrm{cm}$ from feet shown in the parenthesis.

2. Expression of yield was converted to $\mathrm{Mg} / \mathrm{ha}$ from baskets/acre shown in the parenthesis.

One basket is 9 gallons $(40.9 \mathrm{~L})$ and is equivalent to 46 pounds $(20.87 \mathrm{~kg})$ of unhusked rice. 
area is 38.4 ha (95 acres), in which 16.2 ha (40 acres) are used for hybrid corn seed production.

\section{Objectives and output of the Aung Ban Research Farm}

Objectives of the Aung Ban Research Farm are as follows: 1. to find out suitable varieties and cultivated methods for hilly region crops of maize, upland rice, soybean and wheat; 2 . to produce breeder seeds for maize, upland rice, soybean and wheat. Concerning breeder seeds, they are $99.9 \%$ pure in genotype and phenotype. In producing of seeds, breeder seeds are first produced in small amounts and are multiplied and purified step by step with increased amounts of seeds. In this step breeder seeds are forwarded to foundation seeds and to register seeds and finally to certified seeds which are distributed to farmers as seeds. Seeds are distributed up to Chin State and Shan State (east). Distributed varieties are Kone Myint-2 for upland rice, Shwe War-12 (open pollinated variety), Yezin Hybrid-3 (hybrid) and Yezin Hybrid-5 (hybrid) for maize, and Yezin-3 and SB-60 for soybean. In addition to production of seeds, breeding is made for only maize.

\section{Cropping}

Main crops in the upland agriculture in the highland region of Shan State (south) are upland rice, wheat, maize, sugarcane, garlic, potato, ginger, taro, sweet potato, vegetables, and pulses such as soybean, pigeon pea, butterfly bean and chickpea. In the field of the Aung Ban Research Farm, contour cropping of upland crops is performed. Only wheat was standing, and we heard that in the wheat cultivation $50 \mathrm{~kg} / \mathrm{acre}$ of compound fertilizer $\left(16: 16: 8\right.$ as $\left.\mathrm{N}: \mathrm{P}_{2} \mathrm{O}_{5}: \mathrm{K}_{2} \mathrm{O}\right)$ is applied as basal dressing and $25 \mathrm{~kg} /$ acre of urea as top-dressing after one month or one and a half month after sowing. Yield of wheat is $2.02-2.42 \mathrm{Mg} / \mathrm{ha}$ under the rain-fed condition.

In the farmers' field, upland crops are cultivated in the cropping pattern, for example, of maize - wheat or maize - chickpea without irrigation. In the field survey of this season only wheat and chickpea in the harvested time were standing, and we could see harvesting of wheat and chickpea by hand in the several fields of roadside. Upland rice is sown in the first week of June and is harvested in the last week of October.

Around farmers' house along roadside we saw cultivation of vegetables of cabbage, cauliflower, ginger, potato and chyote and fruits of banana, mango, avocado and jackfruit. Apple, pear and orange are cultivated in the orchard. Among them, apple is newly introduced in this region, and it may be a new development of land use in the highland region of Shan State (south).

\section{Management practice}

Farmers apply compost made of cowdung and chicken excrements but usually do not apply chemical fertilizers. They also do not apply agricultural chemicals, so that resistant varieties are delivered to farmers from the Aung Ban Research Farm. The reasons why farmers do not apply chemical fertilizers and agricultural chemicals are to be high price and that they do not understand well about the effect and components of these chemicals. Some farmers apply N fertilizer; they understand the effect of it not by mechanism but by feeling. The effect of chemical fertilizers is considered to be minor under the rain-fed condition.

\section{NYAUNG OO RESEARCH FARM AND DRYLAND AGRICULTURE IN THE SEMI-ARID REGION}

\section{Dryland agriculture}

Nyaung Oo and Bagan, both being neighboring, in the western side of Mandalay Division is the smallest rainfall area in Myanmar with annual rainfall of 500 to $750 \mathrm{~mm}$. It is characterized as the semi-arid tropical area and is one of the areas suffered from severe drought. The drought in the semi-arid region makes fertilization less effective without irrigation and controls selection of cultivated crops and cropping patterns. According to the letter from Khin Lay Swe (2002; personal communication), sorghum, cotton, sesame, peas and beans are usually cultivated by farmers in Bagan/ Nyaung Oo area. In this farming pigeon pea is used as hedgerow to prevent soil from wind erosion, to conserve soil and water and to reverse soil nutrients.

\section{Location and fundamental data of the Nyaung Oo Research Farm}

The Nyaung Oo Research Farm is located in Nyaung Oo Township, Nyaung Oo District, Mandalay Division. It is named Dry Zone Agriculture Research Centre, Nyaung Oo and has been established as a satellite research farm of CARI (Central Agricultural Research Institute; the former name of the Department of Agricultural Research) since 1981. Dry zone agriculture research program was initiated in 1985 . There are 11 staffs in the Nyaung Oo Research Farm. Among them, 6 persons are Bachelor of Agricultural Science, 2 persons Diploma in Agricultural Science, and 3 persons clerical staffs. In addition, 15 laborers are working.

The following is fundamental data on the Nyaung Oo Research Farm and soil in the farm field: elevation is $62.8 \mathrm{~m}$ (206 feet) above sea level; mean annual rainfall is $603 \mathrm{~mm}$ (23.74 inches); average rainy days in a year is 37 ; mean maximum monthly temperature is $39.05^{\circ} \mathrm{C}$ in April and mean minimum monthly temperature is $14.45^{\circ} \mathrm{C}$ in January; major soil type is Alfisols (Luvisols) with common textural classes of sandy loam and loamy sand; soil pH is 6.0 to 7.5. As located in the semi-arid zone, there is drought in July and maximum rainfall can be obtained in June, August and September. Total area of the research farm is 49.1 ha (121.44 acres) of which 31.5 ha (77.91 acres) are cultivated area and 4.9 ha (12.23 acres) under perennial plants. The rest of 12.7 ha ( 31.30 acres) is occupied with building, roads, ponds and pagoda. Under cultivated area 8.7 ha (21.41 areas) are used for research and 22.9 ha (56.50 acres) for seed production (foundation seeds). 


\section{Objectives and output of the Nyaung Oo Research Farm}

Pulses and edible-oil crops are suitable to dryland agriculture in the semi-arid region of the central Myanmar, and pigeon pea, green gram, groundnut and sesame are targeted crops in the Nyaung Oo Research Farm. Objectives of the Nyaung Oo Research Farm are as follows: 1. to develop locally adapted high-yielding varieties with good quality; 2 . to develop locally adapted production technology; 3 . to distribute quality seed and to demonstrate new production technology to farmers. Until now, the following varieties have been released: Yezin-3 (early variety) for pigeon pea; Yezin-5, Yezin-6 and Yezin-8 for green gram; Sinpadatha-6 and Nyaung Oo-1 for groundnut; Yathekyaw, Maethela and Sinyadana-3 for sesame. In addition, intercropping systems of pigeon pea-green gram, pigeon pea-groundnut, and pigeon pea-sesame were established as pigeon pea-based cropping systems and disseminated to farmers.

\section{Rainfall}

Rainfall occurs surely one time in May. It is dry in June and July, but it rains well in August and September and little in October. The crops having the life period of 4 months are grown with moisture of August and September.

\section{Soils}

Soil types distributed in Nyaung Oo District by the England system are as follows: Red Brown Savanna; Reddish Brown Savanna; Light Reddish Brown Savanna; Shallow Reddish Brown Savanna; Brown Savanna; Yellow Brown Savanna. All soils are classified to "Savanna", reflecting rainfall characteristics and temperature. The soil color suggests more or less strong weathering of soil under the tropical monsoon climate. It is considered that no deposition of the sediments of the Ayeyarwady River has occurred since long time probably except the narrow area along the river.

\section{Cropping}

In the semi-arid region of Nyaung Oo, dryland agriculture is carried out under the rain-fed condition without application of chemical fertilizers. As stated, main crops are pigeon pea, green gram, groundnut and sesame. Sorghum and millets are cultivated for livestock feeding. In this region wheat cannot be grown, because soil is sandy. The main cropping pattern is as follows: in the first cropping green gram or early sesame (rainyseason sesame) is grown; in the second cropping pigeon pea is intercropped with green gram, groundnut and sesame (late sesame). Early sesame is a photo-period insensitive variety, while late sesame is a photo-period sensitive variety and cannot be grown in the rainy season. Pigeon pea is mainly exported and is not for eating, because other peas and beans such as chickpea and green gram are preferably eaten. But, old people have used pigeon pea for medicinal effect. In the present, cultivation of pigeon pea is for getting fuel as well as for harvest. The crop yield is as follows: 0.56$0.81 \mathrm{Mg} / \mathrm{ha}$ (7-10 baskets/acre) as seed for pigeon pea; $0.81-1.21 \mathrm{Mg} / \mathrm{ha}$ (10-15 baskets/acre) as seed for green gram; $0.56-1.40 \mathrm{Mg} / \mathrm{ha}$ (20-50 baskets/acre) as pod for groundnut. These yields can be compared with those of the national level shown in Table 3. Here, one basket is equal to 72 pounds in pigeon pea and green gram (seed) and to 25 pounds in groundnut (pod). The volumetric counting system of Myanmar is set up by can-pyibasket, and 8 cans are equal to one pyi and 16 pyis to one basket.

In the field of the Nyaung Oo Research Farm, pigeon pea was intercropped with green gram, groundnut and sesame. In this season, we could see only stems of pigeon pea after harvesting. In the intercropping, pigeon pea is first sown as a hedge row, and green gram, groundnut and sesame are grown between hedge rows of pigeon pea. Pigeon pea is sown in May and is intercropped in July. The distance between the pigeon pea hedge rows is $1.5 \mathrm{~m}$ and the height of the hedge row is $1 \mathrm{~m}$ at the time of intercropping. Pigeon pea is harvested after 8 months from sowing. Green gram is harvested after 2 months from seeding, while groundnut and sesame is harvested after 3 months from seeding. Irrigation is not used in the field of Nyanug Oo Research Farm. Chemical fertilizers are not used but farmyard manure is applied.

In one farmer's field cotton was planted as a hedge row instead of pigeon pea. The distance between cotton hedge rows was $18 \mathrm{~m}$. Cotton stem and root are used for fuel. In another farmer's field the distance between pigeon pea hedge rows was $5 \mathrm{~m}$. Roots of the previous pigeon pea are dug out for fuel in May when next pigeon pea is sown. In the farmers' field, they use urea for paddy but not for upland crops because of price.

Cropping sequence and intercropping in Nyaung Oo region are as follows. Pigeon pea or cotton is seeded in May with a distance of 5 to $15 \mathrm{~m}$. Sesame is intercropped in May. If the soil moisture is not enough, sesame is destroyed, and green gram (2 months period crop) is grown. After green gram cultivation farmers grow groundnut, sesame, lab-lab bean or horse bean. In the border of the field sorghum is cultivated.

\section{Irrigation}

It is irrigated partly in Nyaung Oo region, and some farmers use irrigation for cropping. There are 5 pumping stations along the Ayeyahwaday River in Nyaung Oo District. Among the 5 stations the Law Ka Nandar pumping station is the biggest one. Irrigation by the 5 pumping stations covers 4,856 ha $(12,000$ acres) of agricultural land, if electric power supply to the pumping stations is enough. The pumped up water is mainly used for irrigation and drinking.

The Law Ka Nandar pumping station under control of the Government (Ministry of Agriculture and Irrigation) was constructed in 2001 to 2003 on a branch of the Ayeyahwady River. Pumping and delivering of water were started in 2003. The Law Ka Nandar pumping station can cover up to 2,023 ha (5,000 acres) of the 
irrigated area for rice in the rainy season. It also covers the same area in the summer (hot) season, but the summer-season (dry-season) crops do not require much water. We had a chance to visit the Law Ka Nandar pumping station and to see the cropping pattern of rice - rice - groundnut for demonstration in the field near the pumping station. The Government wants to order to grow rice twice a year in the irrigated area. The cropping pattern of rice (summer paddy) - groundnut green gram is also recommended, but farmers want to grow only pulses.

\section{Drinking water and the Ayeyarwady River}

Long time ago, drinking water was very scarce in Nyaung Oo region. In the present, people take drinking water form the Ayeyarwady River. So, the Ayeyarwady River is very important for agriculture and living. In case of provision of drinking water to the villages such as the Taung $\mathrm{Ba}$ village, one of the Pyu villages which continue from the time before the Pagan era of 10th 13th centuries in Nyaung Oo, it starts from the Ayeyarwady River. There is a big pumping station by the Ayeyarwady River. The Ayeyarwaday river water is kept in a large depression when the water level is high. Water is pumped up at the pumping station from that depression in the river and is sent to another place, which is about 5 miles far from the first pumping station. Water is then pumped up again and again to the Taung Ba village, which is about 20 miles far from the first station. There is a water station in the village, and water is supplied to village people at the water station two times in a day. Water is carried to houses by a tub loaded on the cattle-drawn carriage or in the manpushing court, or two buckets on the young lady's shoulder, and used for drinking and cooking. It saves the time for carrying water from the source outside the village and contributes to health of village people.

\section{ACKNOWLEDGEMENTS}

We express our sincere thanks to Mr. U Myint Soe, Farm Manager, and Mr. Ko Hla Oo, Junior Research Assistant, of Tayraw Research Farm, Ms. Daw Win Thida Oo, Senior Research Assistant, of Aung Ban Research Farm, and Ms. Daw Khin Myint Kyi, Farm Manager, of Nyaung Oo Research Farm, for their warm hospitality to our visiting, and nice introduction of farm activities and kind guidance of field survey.

\section{REFERENCES}

Egashira, K. 2002a Statistics on agricultural population and land, and crop production of the Red River basin, Viet Nam. Sci. Bull Fac. Agric., Kyushu Univ., 57: 85-98 (in Japanese)

Egashira, K. 2002b Statistics on agricultural population, land use, and production of cereals in southeastern and southern Asian countries. Sci. Bull Fac. Agric., Kyushu Univ., 57: 99-108 (in Japanese)

Kurosawa, K. and K. Egashira 2004 Comparison and future prediction on agricultural indexes in countries of Southeast Asia -characterization of agriculture in terms of annual changes in the arable-land area, consumption of nitrogen fertilizer and production of principal crops during the past 25 years-. Jps. J. Soil Sci. Plant Nutr., 75: 125-133 (in Japanese)

Ministry of Agriculture and Irrigation 2000 Myanma Agriculture Service and Current Situation of Some Major Crops. Yangon (Myanmar), 32 pp.

Ministry of Agriculture and Irrigation 2004 Myanmar Agriculture in Brief. Yangon (Myanmar), 39 pp. 